\section{High glucose attenuates insulin- induced VEGF expression in bovine retinal microvascular endothelial cells}

\author{
Abstract \\ Purpose To investigate the effect of high \\ glucose on insulin-induced vascular \\ endothelial growth factor (VEGF) expression \\ in bovine retinal microvascular endothelial \\ cells (BRECs) and to probe into related \\ mechanisms. \\ Methods BRECs were isolated as primary \\ cultures and identified by immunostaining. \\ Passage cells were initially exposed to normal \\ $(5 \mathrm{mM})$ or high glucose $(30 \mathrm{mM})$ for 3 days, and \\ equimolar L-glucose was supplemented for \\ osmotic equation. BRECs were then treated \\ with $100 \mathrm{nM}$ insulin for $24 \mathrm{~h}$ or not, and cells \\ were prepared for the determination of VEGF \\ mRNA expression by real-time PCR. VEGF \\ protein was determined by human umbilical \\ vein endothelial cell proliferation assay, \\ immunofluorescence, and ELISA. BRECs were \\ treated with 5 or $30 \mathrm{mM}$ glucose for 3 days and \\ then cells cultured with $5 \mathrm{mM}$ glucose were \\ exposed to the PI3-K inhibitor wortmannin \\ $(100 \mathrm{nM})$, the P42/44 mitogen-activated protein \\ kinase (MAPK) inhibitor U0126 $(50 \mu \mathrm{M})$, or to \\ the protein kinase $C$ (PKC) inhibitor \\ GF109203X ( $2 \mu \mathrm{M}) 1 \mathrm{~h}$ before addition of \\ $100 \mathrm{nM}$ insulin. Twenty-four hours after \\ incubation with insulin, the cells were \\ subjected to real-time PCR and ELISA \\ analyses. \\ Results Insulin or high glucose alone \\ markedly increased VEGF mRNA and protein \\ levels in BRECs $(P<0.05$, two-way ANOVA). \\ However, the combination of insulin and high \\ glucose displayed a weaker effect in \\ promoting VEGF expression than did insulin \\ alone $(P<0.05, t$-test $)$. Pretreatment of cells \\ with PI3-K inhibitor significantly $(P<\mathbf{0 . 0 5}$, \\ one-way ANOVA) suppressed the insulin- \\ induced VEGF expression; neither
}

$\mathrm{HWU}^{1,2}, \mathrm{XXia^{1 } , \mathrm { C } \text { Jiang } ^ { 2 } , \mathrm { J } \mathrm { Wu } ^ { 2 } , \mathrm { S } \text { Zhang }}{ }^{2}$, Z Zheng ${ }^{1}$, W Liư ${ }^{2}, Y$ Zhang ${ }^{2}, \mathrm{H}$ Ren $^{2}, \mathrm{C} \mathrm{Wei}^{2}$ and $\mathrm{XX \textrm {Xu } ^ { 1 }}$

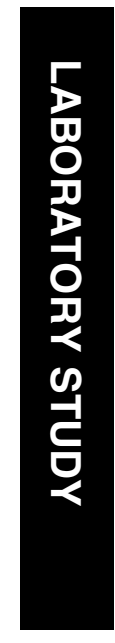

pretreatment with the PKC inhibitor nor with the P42/p44 MAPK inhibitor showed an effect on the expression of VEGF at the mRNA or protein level ( $P>0.05$, one-way ANOVA). Conclusions Both insulin and high glucose can markedly increase VEGF expression in BRECs at the mRNA and protein level. We propose that insulin may upregulate VEGF expression through the PI3-K signalling pathway in BRECs, and high glucose may attenuate insulin-induced VEGF expression by impairing PI3-K signalling pathways. Eye (2010) 24, 145-151; doi:10.1038/eye.2009.157; published online 26 June 2009

Keywords: diabetic retinopathy; endothelium; insulin; vascular endothelial growth factor; retina

\section{Introduction}

Vascular endothelial growth factor (VEGF) as a potent angiogenic factor can stimulate capillary formation and enhance cell permeability. ${ }^{1-3}$

Both preclinical and clinical studies have shown that VEGF participated in the pathogenesis of proliferative diabetic retinopathy. ${ }^{4-6}$ Moreover, intraocular VEGF was found increased in the eyes of diabetic patients with blood-retinal barrier breakdown and neovascularization. ${ }^{4-6}$ Notably, inhibition of VEGF activity can prevent neovascularization and blood-retinal barrier breakdown in animal models. ${ }^{6-9}$ Recently, insulin has been reported to increase the expression of VEGF in multiple cell types, including epithelial cells, ${ }^{10}$ fibroblasts, ${ }^{11}$ and other cells. ${ }^{12}$ Moreover, insulin-induced VEGF expression was thought to be associated with

\author{
${ }^{1}$ Department of \\ Ophthalmology, The First \\ People's Hospital Affiliated \\ to Shanghai Jiaotong \\ University, Shanghai, China \\ ${ }^{2}$ Department of \\ Ophthalmology, Eye Ear \\ Nose and Throat Hospital \\ Affiliated to Fudan \\ University, Shanghai, China
}

Correspondence: $\mathrm{XX \textrm {X }}$, Department of Ophthalmology, The First People's Hospital Affiliated to Shanghai Jiaotong University, No. 85 Wujin Road, Shanghai 200080,

China

Tel: +862163240090

Ext 6842;

Fax: + 862163067385 .

E-mail:drxuxun@

163.com

Received: 14 November 2008

Accepted in revised form: 31 May 2009 Published online: 26 June 2009 
the transient worsening of diabetic retinopathy after acute intensive insulin therapy. ${ }^{10}$

VEGF is present in various cell types and its expression is regulated by a number of growth factors and cytokines, such as interleukin-1- $\beta{ }^{13}$ platelet-derived growth factor (PDGF), and transforming growth factor $\beta .{ }^{14}$ PDGF has been reported to stimulate VEGF expression in NIH3T3 fibroblasts in a Ras- and Raf-dependent manner. ${ }^{15}$ However, the precise molecular mechanism by which growth factors induce VEGF expression remains poorly understood. Reportedly, insulin-induced VEGF expression was mediated by the activation of phosphatidylinositol 3-kinase/Akt (PI-3K), a downstream element of the insulin receptor. However, almost all the in vitro studies showing an insulinenhanced VEGF expression were conducted under a normal glucose level $(5 \mathrm{mM})$. In fact, the blood glucose level is high in diabetic patients before the initiation of insulin therapy. Therefore, it is of great clinical significance to investigate the VEGF expression in cells exposed to high glucose. This study is aimed at investigating whether insulin can increase VEGF expression in bovine retinal microvascular endothelial cells (BRECs) exposed to higher glucose $(30 \mathrm{mM})$, as it does in those exposed to normal glucose $(5 \mathrm{mM})$, and to preliminarily investigate the related mechanisms.

We used real-time polymerase chain reaction (real-time PCR) to examine the VEGF mRNA expression in BRECs treated with different combinations of insulin and glucose. In vitro proliferation assay of human umbilical vein endothelial cells (HUVECs), immunofluorescence, and ELISA were used to examine the expression of the VEGF protein. To further understand the mechanism underlying the changes of VEGF expression, we also determined the VEGF expression in BRECs pretreated with the inhibitors of PI3-K, and P42/44 mitogenactivated protein kinase (MAPK) and protein kinase $C$ (PKC) pathways before the addition of insulin.

\section{Methods}

\section{Cell culture and study design}

BRECs were isolated by homogenization and by a series of filtration steps as we described earlier. ${ }^{16}$ The cells were subsequently cultured with Dulbecco's modified Eagle's medium supplemented with 10\% FBS (GIBCO), $100 \mathrm{mg} / 1$ heparin (Sigma), $10 \mathrm{mmol} / 1$ HEPES (GIBCO), and $15 \mathrm{mg} / 1$ ECGS (Sigma). The culture plate (corning) was coated with Gelatin (Sigma) beforehand. The cells were cultured in $5 \% \mathrm{CO}_{2}$ at $37^{\circ} \mathrm{C}$ and the media were changed every 3 days. Thereafter, the cells were characterized for their homogeneity using an immunoreactivity test with anti-factor VIII antibody for BRECs. ${ }^{16,17}$ Only cells of passages 5-10 were used for this study. Cells were seeded into $60 \mathrm{~mm}$ plates $\left(5 \times 10^{4}\right.$ cells $\left./ \mathrm{ml}, 4 \mathrm{ml}\right)$ and were incubated with 5 or $30 \mathrm{mM}$ glucose for 3 days. L-glucose $(25 \mathrm{mM})$ was supplemented to the $5 \mathrm{mM}$ group for osmotic equation. The cells were serum-deprived overnight in Dulbecco's modified Eagle's medium containing $0.2 \% \mathrm{w} / \mathrm{v}$ bovine serum albumin and were then incubated with either $100 \mathrm{nM}$ insulin (Sigma) or not for $24 \mathrm{~h}$. The experiment was therefore divided into four groups: group A (5 mM glucose), group B ( $5 \mathrm{mM}$ glucose $+100 \mathrm{nM}$ insulin), group C ( $30 \mathrm{mM}$ glucose), and group D (30 mM glucose $+100 \mathrm{nM}$ insulin).

To investigate the mechanisms underlying insulininduced VEGF expression, BRECs were divided into the following five groups: $5 \mathrm{mM}$ glucose $+100 \mathrm{nM}$ insulin group, $5 \mathrm{mM}$ glucose + wortmannin $+100 \mathrm{nM}$ insulin group, $5 \mathrm{mM}$ glucose $+\mathrm{U} 0126+100 \mathrm{nM}$ insulin group, $5 \mathrm{mM}$ glucose $+\mathrm{GF} 109203 \mathrm{X}+100 \mathrm{nM}$ insulin group, and $30 \mathrm{mM}$ glucose $+100 \mathrm{nM}$ insulin group. BRECs were treated with 5 or $30 \mathrm{mM}$ glucose for 3 days; thereafter, the cells cultured with $5 \mathrm{mM}$ glucose were exposed to the PI3-K inhibitor wortmannin (100 nM), to the P42/44 MAPK inhibitor U0126 $(50 \mu \mathrm{M})$, or to the PKC inhibitor GF109203X ( $2 \mu \mathrm{M})$ (all from Calbiochem, EMD Biosciences, La Jolla, CA) $1 \mathrm{~h}$ before the addition of $100 \mathrm{nM}$ insulin. The cells were incubated with insulin for $24 \mathrm{~h}$ and then used for real-time PCR and ELISA analyses.

\section{Quantitative real-time PCR analysis of VEGF mRNA}

VEGF mRNA expression was analyzed by quantitative RT-PCR, which was carried out using Rotor-Gene 3000 (Corbett Research, USA). Primers were designed to generate a PCR product of the $162 \mathrm{bp}$ bovine VEGF gene (Accession NM_174216; forward, 5'-TTCCAGGAGT ACCCAGATGAGA-3', and reverse, 5'CTGGCTTTGGT GAGGTTTGAT3'). The housekeeping gene, bovine $\beta$-actin (Accession NM_173979; forward, 5'CCTGTA CGCCAACACAGTGC3'; Reverse 5' ATACTCCTGC TTGCTGATCC $3^{\prime}$ ), was used as an internal standard.

\section{Proliferation assay of HUVECs}

To further understand the VEGF protein expression of each group, the supernatants of each group were used to stimulate the proliferation of HUVECs. HUVECs were isolated from umbilical veins by digestion with collagenase as described earlier. ${ }^{18}$ Cells were grown in DMEM supplemented with 10\% FBS (GIBCO) and were used between passages 2 and 4 . HUVECs were then seeded in 12-well plates ( $10^{4}$ cells/well). Twenty-four hours later, the media from Group A, B, C, or D were added to the seeded HUVECs. Four days later, the 
number of cells in each well was determined by two readings with a coulter counter. Each condition was tested in triplicate (mean $\pm \mathrm{SD}, n=3$ ).

\section{Immunofluorescence detection of the VEGF protein expression}

The VEGF protein expression in endothelial cells was detected by an immunofluorescence test. Cultures were fixed with $4 \%$ paraformaldehyde and then reacted with an anti-VEGF antibody (Sigma), followed by Oregon green-labeled secondary antibody (Molecular Probes). For negative controls, the primary antibody was omitted.

\section{Examination of the VEGF protein by ELISA}

Protein samples of each group were extracted and quantified according to earlier described protocols. ${ }^{19,20}$ In brief, protein samples $(50 \mu \mathrm{g})$ were added to wells of a $96-$ well plate coated with VEGF antibody, incubated at $4{ }^{\circ} \mathrm{C}$ overnight, and processed according to the manufacturer's instruction (RayBiotech, Inc, Atlanta, GA, USA). Absorbance was measured in a plate reader at $450 \mathrm{~nm}$. VEGF levels were calculated on the basis of absorbance values by comparing with a standard curve prepared by a six-step serial dilution (from 50 to $3200 \mathrm{pg} / \mathrm{ml}$ ) of recombinant VEGF. The above experiment was repeated twice.

\section{Statistical analysis}

A significance test was carried out using one-way ANOVA, two-way ANOVA, or $t$-test. A $P$-value less than 0.05 was deemed to be statistically significant. All analyses were carried out with SAS 6.12 (Statistics Analytical Software; SAS Institute, Cary, North Carolina, USA).

\section{Results}

High glucose inhibited insulin-induced VEGF mRNA expression

To determine the effects of high glucose on insulininduced VEGF mRNA expression, serum-starved endothelial cells were treated with $100 \mathrm{nM}$ insulin for $24 \mathrm{~h}$, and VEGF mRNA was quantified by real-time PCR. Both insulin and high glucose significantly increased the VEGF mRNA expression in BRECs, compared with low glucose $(P<0.05$, two-way ANOVA). However, the combined effect of insulin and high glucose was weaker $(P<0.05, t$-test) than that with insulin alone (Figure 1$)$.

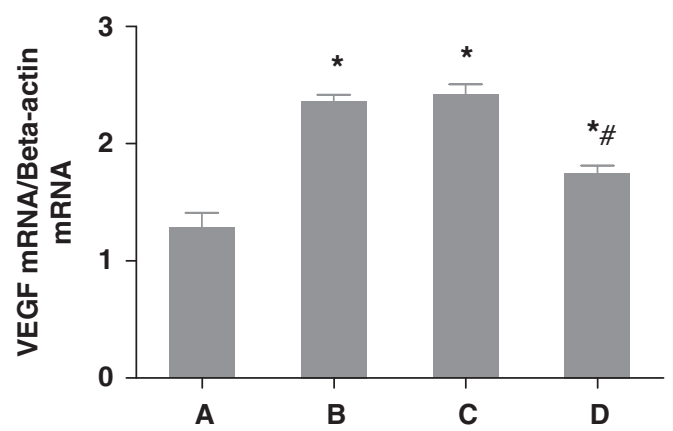

Figure 1 VEGF mRNA expression in BRECs stimulated with insulin or (and) glucose in four groups. Group A: $5 \mathrm{mM}$ glucose; group B: $5 \mathrm{mM}$ glucose $+100 \mathrm{nM}$ insulin; group C: $30 \mathrm{mM}$ glucose; and group D: $30 \mathrm{mM}$ glucose $+100 \mathrm{nM}$ insulin. VEGF mRNA levels were determined by quantitative real-time PCR. The results are expressed as the ratio of VEGF mRNA to $\beta$-actin mRNA, Mean \pm SD for three separate experiments. ${ }^{*} P<0.05$ compared with group A, two-way ANOVA; ${ }^{~} P<0.05$ compared with group $\mathrm{B}, t$-test.

To determine whether there is a peak glucose level that provides the greatest attenuating effect, we conducted the following experiment: BRECs were treated with glucose over a concentration gradient of 5, 10, 15, 20, 25, and $30 \mathrm{mM}$, before exposure to insulin. The greatest attenuation of VEGF expression was observed in the $25 \mathrm{mM}$ group. However, as shown in Figure 2., there was no significant difference between the $25 \mathrm{mM}$ group and the 20 or $30 \mathrm{mM}$ groups.

\section{High glucose attenuated insulin-induced VEGF protein expression}

To ascertain whether the change of VEGF mRNA in BRECs in different groups resulted in corresponding changes in the VEGF protein, we analyzed the protein levels of VEGF in the culture supernatant of each group using endothelial cell proliferation assay. Compared with the medium of group A, the medium of group B increased the number of HUVECs by 1.32-fold ( $29.25 \pm 0.95$ vs $22.25 \pm 1.39, \times 10^{4}, P<0.05$, two-way ANOVA); that of group $C$ increased the number of HUVEC s by 1.33 -fold ( $29.54 \pm 0.72$ vs $22.25 \pm 1.39, \times 10^{4}$, $P<0.05$, two-way ANOVA); and that of group D increased the number of HUVECs by 1.13-fold $\left(25.16 \pm 0.63\right.$ vs $22.25 \pm 1.39, \times 10^{4}, P<0.05$, two-way ANOVA). Moreover, high glucose combined with insulin (group D) had a weaker proliferative effect upon HUVECs than did insulin alone (25.16 \pm 0.63 vs $29.25 \pm 0.95, \times 10^{4}, P<0.05, t$-test $)$.

Immunofluorescence and ELISA were used to examine the protein expression of VEGF under each condition. Immunofluorescence results showed weak VEGF protein 
staining in group A and a strong expression in group B, group $C$ and group $D$. However, the staining result of the VEGF protein in group D was weaker than that in group $B$ (Figure 3.). ELISA results showed that the VEGF protein expression in group A was significantly lower than those in groups B (104.14 \pm 2.20 vs $58.66 \pm 7.62 \mathrm{pg} /$ ml, respectively, $P<0.05$, two-way ANOVA), $C$ $(105.11 \pm 11.14$ vs $58.66 \pm 7.62 \mathrm{pg} / \mathrm{ml}$, respectively, $P<0.05$, two-way ANOVA), and D (78.79 \pm 4.25 vs $58.66 \pm 7.62 \mathrm{pg} / \mathrm{ml}$, respectively, $P<0.05$, two-way ANOVA). Similarly, The VEGF protein expression in group D was significantly lower than that in group B $(78.79 \pm 4.25$ vs $104.14 \pm 2.20 \mathrm{pg} / \mathrm{ml}$, respectively, $P<0.05$, $t$-test $)$.

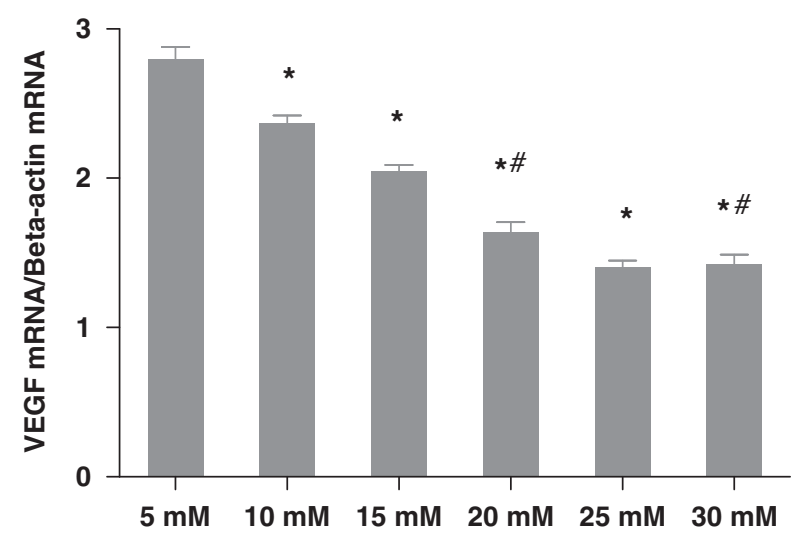

Figure 2 Effect of different concentrations of glucose on insulin-induced VEGF mRNA expression in BRECs. Group A: $5 \mathrm{mM}$ glucose $+100 \mathrm{nM}$ insulin; group $B: 10 \mathrm{mM}$ glucose $+100 \mathrm{nM}$ insulin; group C: $15 \mathrm{mM}$ glucose $+100 \mathrm{nM}$ insulin; group D: $20 \mathrm{mM}$ glucose $+100 \mathrm{nM}$ insulin; group E: $25 \mathrm{mM}$ glucose $+100 \mathrm{nM}$ insulin; group $\mathrm{F}: 30 \mathrm{mM}$ glucose $+100 \mathrm{nM}$ insulin. VEGF mRNA levels were determined by quantitative real-time PCR. The results are expressed as the ratio of VEGF mRNA to $\beta$-actin mRNA, mean \pm SD for three separate experiments. ${ }^{*} P<0.05$ compared with group $\mathrm{A}$, one-way ANOVA; ${ }^{\#} P>0.05$ compared with group $E$, one-way ANOVA. Insulin upregulated VEGF expression in BRECs exposed
to $5 \mathrm{mM}$ glucose through PI3-kinase

A PI3-kinase inhibitor pretreatment of cells exposed to $5 \mathrm{mM}$ glucose significantly suppressed insulin-induced VEGF mRNA and protein expression $(P<0.05$, one-way ANOVA). Pretreatment with inhibitors of PKC and P42/p44 MAPK did not show a significant effect on VEGF mRNA and protein expression. Besides, pretreatment of cells with high glucose also significantly suppressed the insulin-induced VEGF mRNA and protein expression ( $P<0.05$, one-way ANOVA). (Figures 4 and 5). High glucose showed a similar effect as that of the PI3-kinase inhibitor.

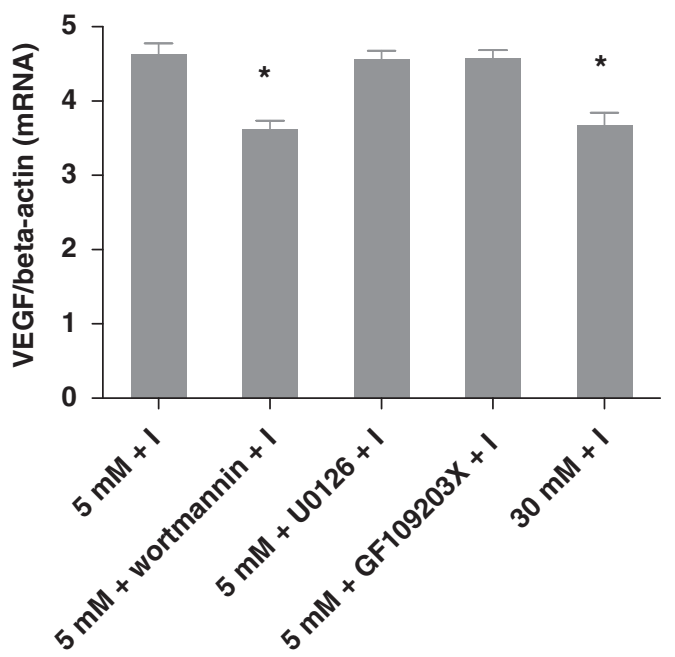

Figure 4 The VEGF mRNA expression in BRECs pretreated with different inhibitors or with high glucose before exposure to insulin. VEGF mRNA levels were determined by quantitative real-time PCR. The results are expressed as the ratio of VEGF mRNA to $\beta$-actin mRNA, mean \pm SD for three separate experiments. Pretreatment of cells with PI3-K inhibitor or high glucose suppressed the insulin-induced VEGF protein expression in BRECs. ${ }^{*}<0.05$ compared with $5 \mathrm{mM}+\mathrm{I}$ group, one-way ANOVA.
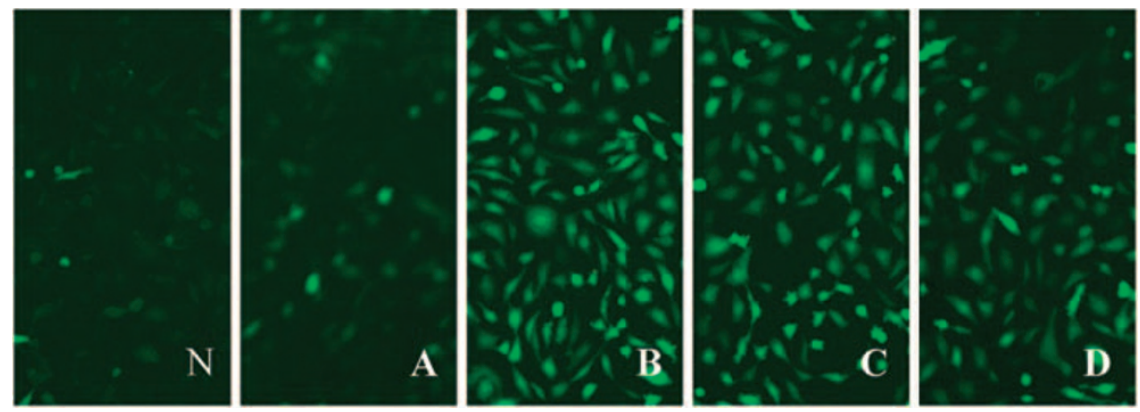

Figure 3 Immunofluorescence for the VEGF protein signal in each group. (N) Negative control, (A) BRECs cultured in $5 \mathrm{mM}$ glucose, (B) BRECs cultured in $5 \mathrm{mM}$ glucose and treated with $100 \mathrm{nM}$ insulin, (C) BRECs cultured in $30 \mathrm{mM}$ glucose, (D) BRECs cultured in $30 \mathrm{mM}$ glucose and treated with $100 \mathrm{nM}$ insulin. 


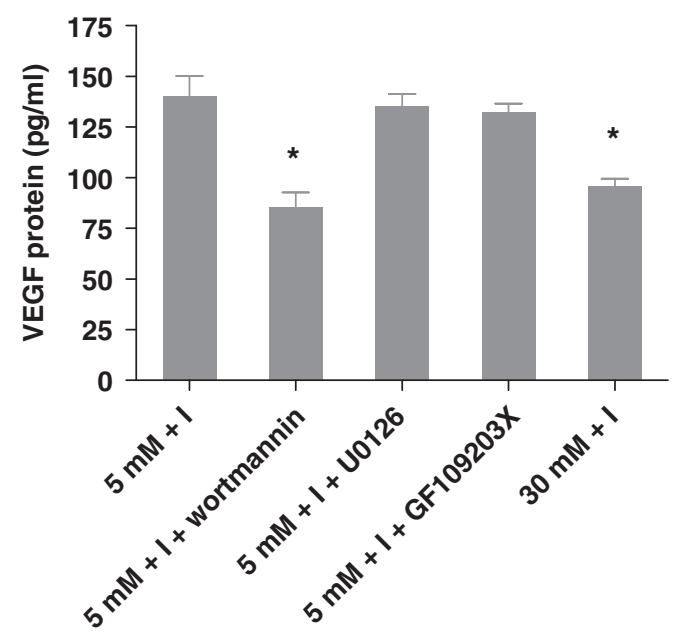

Figure 5 The ELISA examination of the VEGF protein expression in BRECs pretreated with different inhibitors or with high glucose before exposure to insulin. Mean \pm SD for three separate experiments. Pretreatment of cells with the PI3-K inhibitor or with high glucose suppressed the insulin-induced VEGF protein expression in BRECs. ${ }^{*} \mathrm{P}<0.05$ compared with $5 \mathrm{mM}+\mathrm{I}$ group, one-way ANOVA.

\section{Discussion}

This study provides experimental evidence that insulin or high glucose can markedly increase VEGF expression at both mRNA and protein levels in BRECs, and the combined effect of insulin and high glucose is weaker than that of insulin alone. We also prove that pretreatment of cells with PI3-K inhibitor can suppress the insulin-induced VEGF expression. Similarly, the pretreatment of cells with high glucose can also suppress the insulin-induced VEGF expression. Therefore, we hypothesize that high glucose may attenuate insulininduced VEGF expression by impairing PI3-K signalling pathways.

The mechanisms underlying the effect of insulin on VEGF expression have been extensively studied. Many studies have shown that the activation of the PI3-K/Akt pathway can upregulate the expression of hypoxiainducible factor- $1 \alpha$ (HIF- $1 \alpha),{ }^{10,11,21}$ and subsequently increase VEGF expression by directly interacting with VEGF promoter. ${ }^{10}$ Miele $\mathrm{C}$ and associates reported that insulin-induced VEGF expression through PI3-K/PKB signalling pathways in NIH3T3 fibroblasts. ${ }^{11}$ Some found that insulin-induced VEGF expression was through both PI3-K and P42/44 MAPK pathways in HepG2 cells and in mouse aortic smooth muscle cells. ${ }^{22,23}$ In this study, we found insulin upregulated VEGF in BRECs through PI3-K signalling pathways.

Although high glucose was found to induce VEGF expression in retinal vascular cells by various mechanisms, ${ }^{24-26}$ this study found that the combined effect of high glucose and insulin was weaker than that of insulin alone, suggesting that high glucose inhibited insulin-induced VEGF expression. Through a concentration gradient experiment, we found that the greatest attenuation of VEGF expression was in the $25 \mathrm{mM}$ group, but there was no significant difference between the $25 \mathrm{mM}$ group and the 20 or $30 \mathrm{mM}$ groups. In similar studies, $30 \mathrm{mM}$ is used as a high concentration for glucose. ${ }^{27,28}$ In this study, we also used $30 \mathrm{mM}$ as the highest concentration. Further, we found that, similar to high glucose, the PI3-K inhibitor also inhibited insulininduced VEGF expression, but inhibitors of PKC or P42/ p44 MAPK hardly showed any inhibitory effect against the insulin-induced VEGF expression. Therefore, we assume that high glucose might inhibit insulin-induced VEGF expression through impairing PI3-K signalling pathways. Matthew and associates reported that chronic insulin and high glucose synergistically inhibit the interleukin-4-dependent activation of PI3-kinase in macrophages through the mTOR pathway. ${ }^{29}$ Tahir reported that high glucose impaired receptor and insulin receptor substrate-1 phosphorylation by $34 \%$.

Phosphatidylinositol 3-kinase activity was decreased by $85 \%$. The impairment of insulin receptor substrate-1 tyrosine phosphorylation is greater than that of the insulin receptor, resulting in attenuated phosphatidylinositol 3-kinase activation and mitogenic signalling. ${ }^{30}$ Other studies indicated that high glucose inhibited hypoxia-induced VEGF response in cultured proximal tubular cells at both mRNA and protein levels. ${ }^{31}$ Besides, high glucose was also reported to inhibit insulin-stimulated nitric oxide production by impairing molecular (IRS-1, PI 3-kinase) and functional insulin signals in vascular endothelial cells. ${ }^{32}$ These findings are consistent with the results of this study that show that high glucose may attenuate insulin-induced VEGF expression by impairing the PI 3-K signalling pathway.

Earlier studies have indicated that insulin-induced VEGF expression was associated with the transient worsening of diabetic retinopathy after acute intensive insulin therapy..$^{10}$ However, almost all these in vitro studies, which showed that insulin enhanced VEGF expression, were conducted under a normal glucose level. In fact, the blood glucose level is high in diabetic patients before the initiation of insulin therapy. Our study found that when insulin is administered to high glucose-exposed BRECs, which mimics the real condition of diabetic patients, the expression of VEGF is decreased; hence, we propose that the transient worsening of diabetic retinopathy after insulin therapy is not related to VEGF expression alone. Besides the VEGF increase, other reasons such as insulin-induced intracellular reactive 
oxygen species (ROS) production and pericyte loss may also be contributing factors. ${ }^{33}$ Another study by our group showed that insulin treatment significantly increased intracellular ROS production in BRECs exposed to $30 \mathrm{mM}$ (data not shown). Therefore, we suggest that more efforts should be made to search for other factors that contribute towards the worsening of diabetic retinopathy and the corresponding treatment.

In summary, both insulin and high glucose can markedly increase the VEGF expression in BRECs at the mRNA and protein level. We propose that insulin may upregulate VEGF expression through the PI3-K signalling pathway in BRECs, and high glucose may attenuate insulin-induced VEGF expression by impairing PI3-K signalling pathways. However, further study is necessary to clarify the precise causes of the reduced VEGF expression in the presence of an elevated glucose level.

\section{Acknowledgements}

The work was funded by the Youth Foundation of the Shanghai Health Bureau (2008Y098), the Shanghai Vision Rehabilitation Clinical Center (FM-040102-206), and the Foundation of the First People's Hospital Affiliated to Shanghai Jiaotong University (07B42). The authors thank $\mathrm{Yu}$ Danghui of the Second Military Medical University Press for his careful reading of the English language.

\section{Conflict of interest}

The authors declare no conflict of interest.

\section{References}

1 Ferrara N, Houck K, Jakeman L, Leung DW. Molecular and biological properties of the vascular endothelial growth factor family of proteins. Endocr Rev 1992; 13: 18-32.

2 Thomas KA. Vascular endothelial growth factor, a potent and selective angiogenic agent. J Biol Chem 1996; 271 603-606.

3 Eyries M, Collins T, Khachigian LM. Modulation of growth factor gene expression in vascular cells by oxidative stress. Endothelium 2004; 11: 133-139.

4 Adamis AP, Miller JW, Bernal MT, D'Amico DJ, Folkman J, Yeo TK et al. Increased vascular endothelial growth factor levels in the vitreous of eyes with proliferative diabetic retinopathy. Am J Ophthalmol 1994; 118: 445-450.

5 Aiello LP, Avery RL, Arrigg PG, Keyt BA, Jampel HD, Shah $\mathrm{ST}$ et al. Vascular endothelial growth factor in ocular fluid of patients with diabetic retinopathy and other retinal disorders. N Engl J Med 1994; 331: 1480-1487.

6 Aiello LP, Pierce EA, Foley ED, Takagi H, Chen H, Riddle L et al. Suppression of retinal neovascularization in vivo by inhibition of vascular endothelial growth factor (VEGF) using soluble VEGF-receptor chimeric proteins. Proc Natl Acad Sci USA 1995; 92: 10457-10461.
7 Malecaze F, Clamens S, Simorre-Pinatel V, Mathis A, Chollet $\mathrm{P}$, Favard C et al. Detection of vascular endothelial growth factor messenger RNA and vascular endothelial growth factor-like activity in proliferative diabetic retinopathy. Arch Ophthalmol 1994; 112: 1476-1482.

8 Murata T, Ishibashi T, Khalil A, Hata Y, Yoshikawa H, Inomata $\mathrm{H}$. Vascular endothelial growth factor plays a role in hyperpermeability of diabetic retinal vessels. Ophthalmic Res 1995; 27: 48-52.

9 Adamis AP, Shima DT, Tolentino MJ, Gragoudas ES, Ferrara $\mathrm{N}$, Folkman J et al. Inhibition of vascular endothelial growth factor prevents retinal ischemia-associated iris neovascularization in a nonhuman primate. Arch Ophthalmol 1996; 114: 66-71.

10 Poulaki V, Qin W, Joussen AM, Hurlbut P, Wiegand SJ, Rudge $\mathrm{J}$ et al. Acute intensive insulin therapy exacerbates diabetic blood-retinal barrier breakdown via hypoxiainducible factor-1alpha and VEGF. J Clin Invest 2002; 109: 805-815.

11 Miele C, Rochford JJ, Filippa N, Giorgetti-Peraldi S, Van Obberghen E. Insulin and insulin-like growth factor-I induce vascular endothelial growth factor mRNA expression via different signaling pathways. J Biol Chem 2000; 275: 21695-21702.

12 Bermont L, Lamielle F, Lorchel F, Fauconnet S, Esumi H, Weisz A et al. Insulin up-regulates vascular endothelial growth factor and stabilizes its messengers in endometrial adenocarcinoma cells. J Clin Endocrinol Metab 2001; 86: 363-368.

13 Li J, Perrella MA, Tsai JC, Yet SF, Hsieh CM, Yoshizumi M et al. Induction of vascular endothelial growth factor gene expression by interleukin- 1 beta in rat aortic smooth muscle cells. J Biol Chem 1995; 270: 308-312.

14 Brogi $\mathrm{E}, \mathrm{Wu} \mathrm{T}$, Namiki A, Isner JM. Indirect angiogenic cytokines upregulate VEGF and bFGF gene expression in vascular smooth muscle cells, whereas hypoxia upregulates VEGF expression only. Circulation 1994; 90: 649-652.

15 Grugel S, Finkenzeller G, Weindel K, Barleon B, Marme D. Both v-Ha-Ras and v-Raf stimulate expression of the vascular endothelial growth factor in NIH 3T3 cells. J Biol Chem 1995; 270: 25915-25919.

16 Cui $\mathrm{Y}, \mathrm{Xu} \mathrm{X}, \mathrm{Bi} \mathrm{H}, \mathrm{Zhu} \mathrm{Q}, \mathrm{Wu} \mathrm{J}$, Xia X et al. Expression modification of uncoupling proteins and MnSOD in retinal endothelial cells and pericytes induced by high glucose: the role of reactive oxygen species in diabetic retinopathy. Exp Eye Res 2006; 83: 807-816.

17 Nayak RC, Berman AB, George KL, Eisenbarth GS, King GL. A monoclonal antibody (3G5)-defined ganglioside antigen is expressed on the cell surface of microvascular pericytes. J Exp Med 1988; 167: 1003-1015.

18 Barbieri B, Balconi G, Dejana E, Donati MB. Evidence that vascular endothelial cells can induce the retraction of fibrin clots. Proc Soc Exp Biol Med 1981; 168: 204-207.

19 Bartoli M, Gu X, Tsai NT, Venema RC, Brooks SE, Marrero $\mathrm{MB}$ et al. Vascular endothelial growth factor activates STAT proteins in aortic endothelial cells. J Biol Chem 2000; 275: 33189-33192.

20 Platt DH, Bartoli M, El-Remessy AB, Al-Shabrawey M, Lemtalsi T, Fulton D et al. Peroxynitrite increases VEGF expression in vascular endothelial cells via STAT3. Free Radic Biol Med 2005; 39: 1353-1361.

21 Zelzer E, Levy Y, Kahana C, Shilo BZ, Rubinstein M, Cohen B. Insulin induces transcription of target genes through the 
hypoxia-inducible factor HIF-1alpha/ARNT. EMBO J 1998; 17: 5085-5094.

22 Carnesecchi S, Carpentier JL, Foti M, Szanto I. Insulininduced vascular endothelial growth factor expression is mediated by the NADPH oxidase NOX3. Exp Cell Res 2006; 312: 3413-3424.

23 Jiang ZY, He Z, King BL, Kuroki T, Opland DM, Suzuma K et al. Characterization of multiple signaling pathways of insulin in the regulation of vascular endothelial growth factor expression in vascular cells and angiogenesis. J Biol Chem 2003; 278: 31964-31971.

24 Amano S, Yamagishi S, Inagaki Y, Nakamura K, Takeuchi $\mathrm{M}$, Inoue $\mathrm{H}$ et al. Pigment epithelium-derived factor inhibits oxidative stress-induced apoptosis and dysfunction of cultured retinal pericytes. Microvasc Res 2005; 69: 45-55.

25 El-Remessy AB, Behzadian MA, Abou-Mohamed G, Franklin T, Caldwell RW, Caldwell RB. Experimental diabetes causes breakdown of the blood-retina barrier by a mechanism involving tyrosine nitration and increases in expression of vascular endothelial growth factor and urokinase plasminogen activator receptor. Am J Pathol 2003; 162: 1995-2004.

26 Hata Y, Clermont A, Yamauchi T, Pierce EA, Suzuma I, Kagokawa $\mathrm{H}$ et al. Retinal expression, regulation, and functional bioactivity of prostacyclin-stimulating factor. J Clin Invest 2000; 106: 541-550.

27 Catrina SB, Okamoto K, Pereira T, Brismar K, Poellinger L. Hyperglycemia regulates hypoxia-inducible factor-1alpha protein stability and function. Diabetes 2004; 53: 3226-3232.

28 Nishikawa T, Edelstein D, Du XL, Yamagishi S, Matsumura $\mathrm{T}$, Kaneda $\mathrm{Y}$ et al. Normalizing mitochondrial superoxide production blocks three pathways of hyperglycaemic damage. Nature 2000; 404: 787-790.

29 Hartman ME, O'Connor JC, Godbout JP, Minor KD, Mazzocco VR, Freund GG. Insulin receptor substrate-2dependent interleukin- 4 signaling in macrophages is impaired in two models of type 2 diabetes mellitus. J Biol Chem 2004; 279: 28045-28050.

30 Pillay TS, Xiao S, Olefsky JM. Glucose-induced phosphorylation of the insulin receptor. Functional effects and characterization of phosphorylation sites. J Clin Invest 1996; 97: 613-620.

31 Katavetin P, Miyata T, Inagi R, Tanaka T, Sassa R, Ingelfinger JR et al. High glucose blunts vascular endothelial growth factor response to hypoxia via the oxidative stress-regulated hypoxia-inducible factor/hypoxia-responsible element pathway. J Am Soc Nephrol 2006; 17: 1405-1413.

32 Schnyder B, Pittet M, Durand J, Schnyder-Candrian S. Rapid effects of glucose on the insulin signaling of endothelial NO generation and epithelial Na transport. Am J Physiol Endocrinol Metab 2002; 282: E87-E94.

33 Li W, Liu X, He Z, Yanoff M, Jian B, Ye X. Expression of apoptosis regulatory genes by retinal pericytes after rapid glucose reduction. Invest Ophthalmol Vis Sci 1998; 39: 1535-1543. 